\title{
Twenty Pack
}

National Cancer Institute

\section{Source}

National Cancer Institute. Twenty Pack. NCI Thesaurus. Code C78771.

A product containing twenty individual units. 